\title{
Method Code
}

National Cancer Institute

\section{Source}

National Cancer Institute. Method Code. NCI Thesaurus. Code C93595.

A coded value specifying a means, manner of procedure, or systematic course of actions that have to be performed in order to accomplish a particular goal. 